\title{
VERSITA
}

DOI: 10.2478/tperj-2013-0008

\section{Fruit, Vegatables and Fast Food Consumption among University Students}

\author{
Claudiu AVRAM ${ }^{1}$, Mihaela ORAVITAN ${ }^{2}$
}

\begin{abstract}
Purpose: To establish the prevalence of fruit, vegetables and fast food consumption among students from Timisoara university center and provide evidence based information for increasing healthy food choices in order to prevent cardiovascular diseases. Material and Methods: We perform a cross-sectional study on 435 university students from the Timisoara university center, Romania (mean age: $22 \pm 4.8$ years). The students were recruited using internet and public announcements in the student's campus. All students completed a self administered diet questionnaire. Results: Two thirds of students are not eating fruits and vegetables daily. The prevalence of daily fruit consumption is even lower - $25 \%$. Regarding fast food consumption we found that $26 \%$ of students are often consume these unhealthy products. Three main determinants was identified for choosing unhealthy diet: lack of time, school programme and lack of money. Conclusions: The unhealthy food consumption among students from Timisoara university center is highly prevalent. Increasing students' nutrition-information knowledge and provision of nutrition education is recommended.
\end{abstract}

Key words: fruit, vegetables, fast food, students, cardiovascular prevention.

\section{Rezumat}

Scop: stabilirea prevalenței consumului de fructe, legume şi a produselor fast-food în rândul studenților din centrul universitar Timişoara precum şi furnizarea de informații bazate pe dovezi pentru îmbunătățirea preferințelor alimentare sănătoase în vederea prevenirii bolilor cardiovasculare. Material şi metodă: Am efectuat un studiu transversal care a cuprins 435 studenți din centrul universitar Timişoara, România (vârsta medie: $22 \pm 4.8$ ani). Studenții au fost recrutați prin anunțuri publice postate pe internet şi în campusul universitar. Toți elevii au completat un chestionar auto-administrat cu privire la dietă şi comportamentul alimentardietar. Rezultate: două treimi dintre studenti nu consumă fructe şi legume zilnic. Prevalența consumului zilnic de fructe este chiar mai scăzută - 25\%. În ceea ce priveşte consumul produselor de tip fast-food, am constatat că $26 \%$ dintre studenți consumă frecvent aceste produse. Au fost identificați trei factori determinanți ai alegerilor nesănătoase în ceea ce priveşte dieta: lipsa de timp, programul şcolar şi problemele financiare. Concluzii: consumul de alimente nesănătoase în rândul studenților din centrul universitar Timisoara este foarte răspândit. Sunt recomandate măsuri pentru îmbunătățirea nivelului de informare cu privire la alimentația sănătoasă în rândul tinerilor, în vederea reducerii riscului de boli cardiovasculare.

Cuvinte cheie: fructe, legume, fast-food, studenți, prevenție cardiovasculară.

\footnotetext{
${ }^{1}$ Associate Professor, MD, PhD, Physical Education and Sport Faculty, West University of Timisoara, e-mail: claudiu.avram@gmail.com

${ }^{2}$ Associate Professor, MD, PhD, Physical Education and Sport Faculty, West University of Timisoara
} 


\section{Introduction}

Cardiovascular disease is largely preventable. Diet and physical activity play an important role - seven of the eight risk factors (alcohol use, smoking, high blood pressure, overweight, high blood cholesterol, high blood glucose, low fruit and vegetable intake and physical inactivity) which collectively account for $61 \%$ of cardiovascular deaths are related to diet and physical activity. Reducing exposure to these eight risk factors would increase global life expectancy by almost five years [1].

The studies suggest that eating more portions of fruit and vegetables will significantly reduce the risk of cardiovascular diseases such as coronary heart disease and stroke. The more consumed the greater the risk reduction [2,3].

High proportions of youth do not meet the World Health Organization goal of a daily intake of at least 400 grams of fruit and vegetables [4,5]. Longitudinal studies suggest that eating behaviour in youth tracks into adulthood and those food preferences and eating habits established in adolescence tend to be maintained into adulthood [6]. This fact emphasizes the importance of establishing healthy eating behaviour earlier in life.

The aim of the present study is to establish the prevalence of fruit, vegetables and fast food consumption among students from Timisoara university center and provide evidence based information for increasing healthy food choices in order to prevent cardiovascular diseases.

\section{Material and Methods}

We perform a cross-sectional study on 435 university students from the Timisoara university center, Romania. (mean age: $22 \pm 4.8$ years). The students were recruited using internet and public announcements in the student's campus. All students completed a self administered diet questionnaire.

In the present study we considered "fruit and vegetables" any fresh, frozen, dried and canned fruits and vegetables except potatoes (excluded because these are consumed as starchy staples and are major sources of complex carbohydrates). Fast food refers to food sold in a restaurant or store with preheated or precooked ingredients, and served to the customer in a packaged form for take-out/takeaway.

\section{Results and discussions}

Two thirds of the university students from Timisoara are not eating fruits and vegetables daily. (Figure 1) This findings are far from current guidelines recommendations of 5 portions of fruit and vegetables per day in order to maintain the cardiovascular health [7]. The prevalence of daily fruit consumption is even lower - 25\% (Figure 1 ).

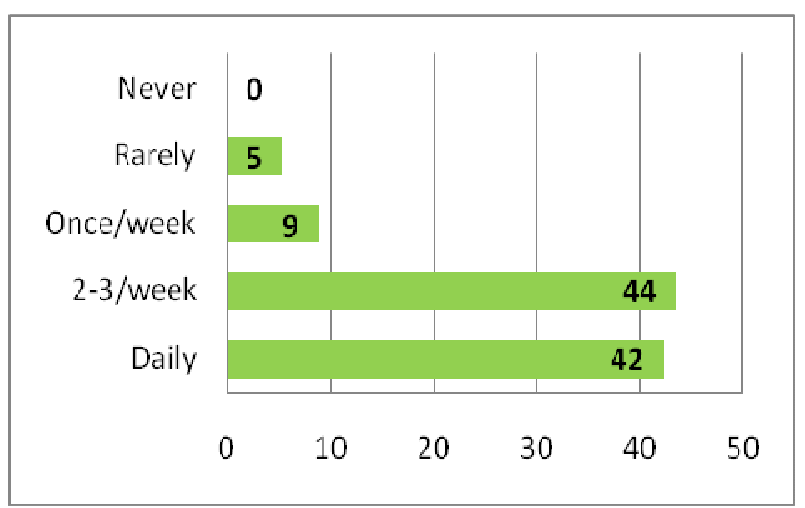

Figure 1. Frequency of fruit and vegetables consumption among students from Timisoara university center.

European Heart Network commissioned a series of scientific reviews to examine the latest evidence and proposed two sets of population goals for fruit and vegetables consumption in order to prevent cardiovascular diseases: An intermediate population goal - more than $400 \mathrm{~g} /$ day; and a longer-term goal more than $600 \mathrm{~g} /$ day [8]. 


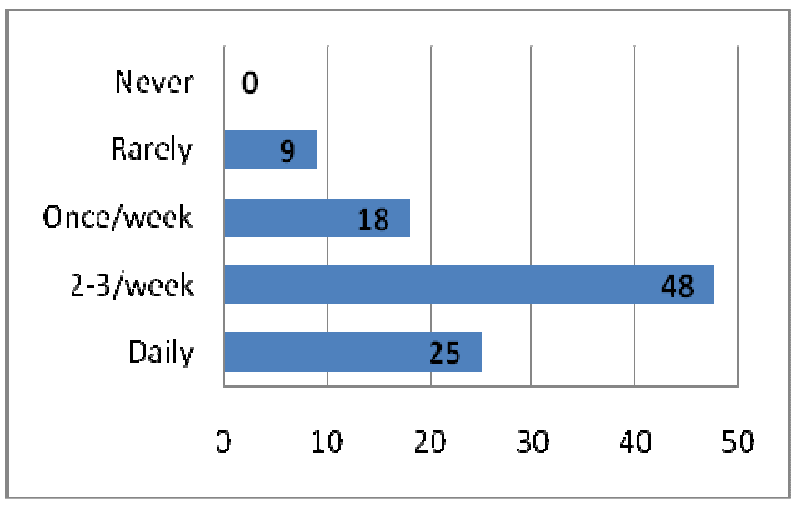

Figure 2. Frequency of fruit consumption among students from Timisoara university center.

While fruit and vegetable consumption has increased, in the last decades, in most European countries, southern European countries (including Romania) have seen meat supplies increase nearly four-fold in a generation [8].

A review of 98 quantitative studies of fruit and vegetable intake among youth showed that the determinants for high consumption levels of fruit and vegetable were female gender, low age, high socio-economic status, high parents intake of fruit and vegetables and high availability of fruit and vegetables at home [9]. We can conclude than that higher age, male gender and low socio-economic status are the three main determinants for low level of fruit and vegetable consumption. This findings are not encouraging due to the fact that the first two determinants are non-adjustable and the last one are hardly changed in the current socio-economical European context.

What are the benefits of fruit and vegetables consumption for the prevention of cardiovascular diseases?

Fruits and vegetables contains high amounts of antioxidants (Polyphenols and vitamins A, E, C) which could influence the blood vessel walls and reduce the inflammatory and endothelial dysfunction and thereby prevent cardiovascular diseases [8].
Polyphenols (flavonoids, phenolic acid, tannins and lignans), highly contained in fruit and vegetables and plant-derived foods and beverages, have been linked to reduced risk of chronic diseases, especially cardiovascular disease [10,11].

The polyphenols mechanisms of action for reducing the risk of chronic diseases go beyond antioxidant functions. Polyphenols influence cell metabolism, through regulation of gene expression and interactions with receptors, enzymes and other proteins [8]. A study of Huxley and collaborators demonstrates the relationship between dietary flavonols (found in high quantities in tea and also in apples, beans, berries, broccoli, onion, red wine, tea, tomato) and coronary heart disease. The study showed that subjects who had a high flavonols intake from fruit and vegetables, had a $20 \%$ reduction in the risk of coronary heart disease [12]. Hollman and collaborators demonstrates in a metaanalysis that intake of flavonols is protective against nonfatal and fatal stroke. The results showed that a high intake of flavonols compared with a low intake is associated with a $20 \%$ decreased risk of stroke incidence [13].

However, polyphenols dietary supplementation (isoflavone) for 2 weeks to 12 months, did not improve endothelial function in postmenopausal women with high baseline endothelial dysfunction, but led to significant improvement in women with low baseline endothelial dysfunction. The results suggests that oral polyphenol supplementation could be effective to targeted subjects, but not to all individuals [14].

The European Food Safety Agency confirmed that vitamin $\mathrm{C}$ and vitamin $\mathrm{E}$ can protect DNA, proteins and lipids from oxidative damage, which is directly related to cardiovascular health [15]. However, a study of Knekt and collaborators who investigate the relation between antioxidant vitamins (vitamins $\mathrm{E}, \mathrm{C}$ 
and beta carotene) and coronary heart disease, showed that the Vitamin C contained in fruit and vegetables did not offer much protection against the incidence of coronary heart disease. Supplementation with vitamin C (>700mg per day) did significantly reduce the coronary heart disease risk by $25 \%$ [16].

Fruit and vegetables are rich in potassium (as are unrefined cereals in general). Studies showed that increasing potassium intake from fruit and vegetables, decrease blood pressure values in the normal blood pressure individuals, with a greater decrease in the high blood pressure individuals [17]. Fruit and vegetables are also rich in dietary fibres which have a distinct metabolic effect. It was estimated that an average goal of 16 to $24 \mathrm{~g} /$ day dietary fibres (for adults) would limit constipation. An upper limit of $24 \mathrm{~g} /$ day (especially as whole grain cereal intakes) increases the intake of phytates and might inhibit the absorption of iron and zinc (important minerals in blood cell formation and immunity defence) [18].

The importance of pectins and guar gums in the dietary fibres of whole grain cereals, fruit and vegetables in lowering blood cholesterol levels is known but is difficult to quantify [8].

There is also studies which demonstrates that increased dietary fibre intake reduce blood pressure and decrease insulin secretion of the pancreas $[19,20]$.

A study of Pereira and collaborators, showed greater protection from fruit fibres than vegetable fibres. Therefore, fruit fibre afforded a $16 \%$ reduction in coronary heart disease risk, compared to no risk reduction from vegetable fibre [21].

Regarding fast food consumption we found that $26 \%$ of students from Timisoara university center, are often consume these unhealthy products (Figure 3 ).
Three main determinants for choosing unhealthy diet identified in students from Timisoara university center: lack of time, school programme and lack of money (Figure 4).

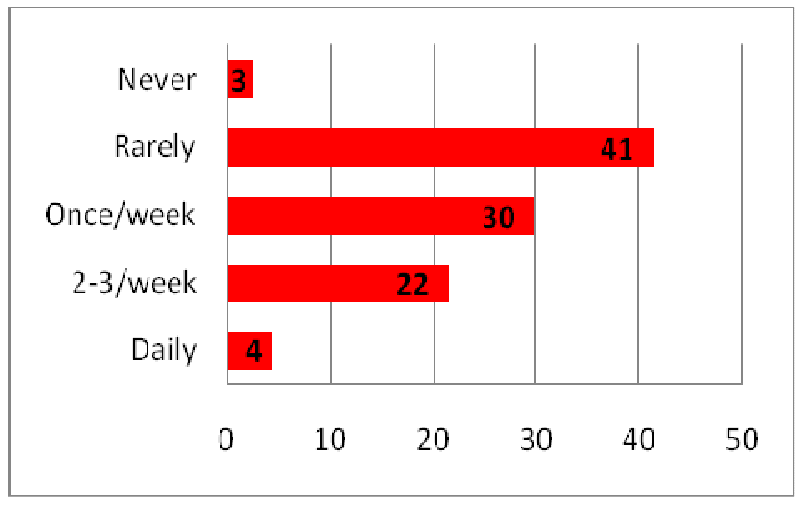

Figure 3. Frequency of fast food consumption among students from Timisoara university center

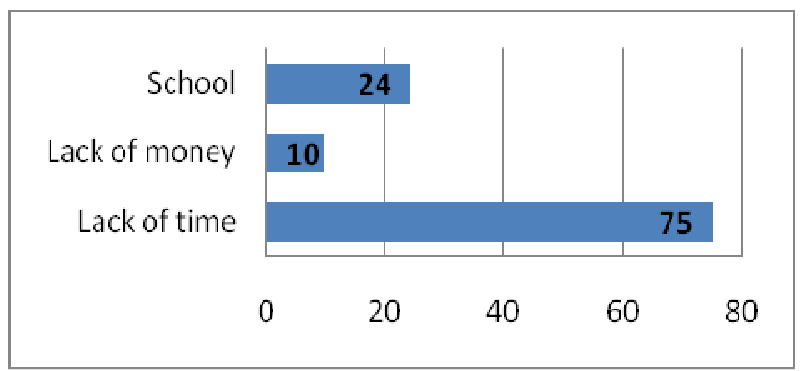

Figure 4. The main reasons for choosing unhealthy diet in students from Timisoara university center

These findings are compliant with the results of a UK national survey which shows that consumption of fast food products is linked to social class differences. Lower income groups (especially young men in lower income groups), are the highest users of fast food restaurants [22].

What are the mechanisms by which fast food consumption threaten cardiovascular health?

The fast food portions are often larger and the food is generally high in calories, saturated and trans fat and low in nutrients and dietary fibres. There are increasing evidence that fast food intake increase the risk of diabetes and cardiovascular diseases. A study recently published article in the American 
Heart Association's journal, found that people who consume fast food even once a week increase their mortality risk from coronary heart disease by 20 percent in comparison to people who avoid fast food [23].

Fast foods contains high amount of trans fatty acids. The trans fatty acids are found in larger quantities in processed foods, where they have been generated from high temperature cooking (French fries), margarines and fats used for baked food (biscuits, pastries, pies). World Health Organization current recommendation for population intakes of trans fatty acids to is below $1 \%$ of total food energy, equivalent to less than 2 grams of trans fat per day [24].

A study conducted in 2005 by Stender and collaborators showed that a standard single portion of French fries and chicken in KFC fast food restaurants from Hungary contains 24 grams of trans fat, this amount being 12 times more than World Health Organization current recommendation [25]. A follow-up of Stender and collaborators study conducted in 2009, found that the amount of trans fatty acids had decreased in north-western European countries, but not significantly in eastern European countries [8].

Salt plays an important role in developing cardiovascular diseases, especially hypertension. The use of salt is likely to be linked to snack foods and fast foods consumption. It confers the processed and potentially poorer-flavoured foods, more palatable and enjoyable taste [8].

\section{The importance of accessibility/affordability of unhealthy food}

The accessibility of low-cost energy dense food is widely spread in many European countries [26]. Economical data show significant growth in sales of snacks, confectionery and soft drinks throughout the south-east European region. Similarly, there is a dramatic rise in fast food restaurants throughout the region over recent decades [8]. The traditional foods are increasingly being replaced by a "modern" diet with a greater proportion of calories coming from oils and fats, sugars and processed starches. In two decades (from 1989 to 2009) the number of McDonald's restaurants - the leading investor in fast foods operating in the European region - increased 1000 times. The McDonald's company, in 2009 had 6,669 company-owned or franchised stores in the European region, serving 12 million meals per day, each meal usualy providing 300-500 kcal with ingredients which are higher saturated and trans fats, sugar and salt and lower in fruit, vegetables and dietary fibre, compared with the recommenddation of dietary guidelines [8].

Several dietary behaviours are linked with unhealthy food intake, including increased number of meals eaten outside the home and snaking (the consumption of foods and drinks between meals including milk drinks, regular soft drinks, sports drinks and energy drinks). In European countries, snacking is highly prevalent [27].

A study conducted by Savige and collaborators showed that the most common contexts for snacking among youth are: after school (4.6 times per week), while watching TV (3.5 times per week) and while hanging out with friends (2.4 times per week) [28]. A study of Jago and collaborators demonstrated that among adolescent males, residing further away from a small food store and close to a fast food restaurant was associated with increased fruit and vegetable consumption [29]. For this reason, it is needed better instruments for limiting accessibility to unhealthy foods (such taxes or restriction of fast food availability in schools or other public institutions). 


\section{The importance of nutritional education}

There is evidence that nutritional education and nutritional labelling encourage choice of "healthier" foods over junk food. Many healthy eating approaches have been centred on increasing fruit and vegetable consumption and providing public health messages about the health benefits of eating fruit and vegetables. Most of them had success in increasing consumption [30]. Messages about the health effects of junk food and social normative messages about intake of junk food can motivate people to reduce their consumption of unhealthy food [31].

European Heart Network calls for "a comprehensive and integrated European food and nutrition policy". The European Heart Network developed a call for action in which promotes the production of more plant-based foods and a shift towards more plantbased diets, with reduced consumption of meat and saturated fat and increased consumption of fruit, vegetables and whole grains. Further progress is needed, in translating these strategic documents into concrete action [8].

\section{Conclusions}

The unhealthy food consumption among students from Timisoara university center is highly prevalent. Increasing students' nutrition-information knowledge and provision of nutrition education is recommendded. More than this, creating an eating environment with more affordable healthy food such fruit and vegetables and less fast food is needed for implementation of effective nutrition strategies in universities.

\section{References}

1. Mackenbach J.P. (2006) Health Inequalities: Europe in Profile. An independent expert report commissioned by the UK Presidency of the EU. London: Department of Health;
2. Mente A., de Koning L., Shannon H.S., Anand S.S. (2009) A systematic review of the evidence supporting a causal link between dietary factors and coronary heart disease. Arch Intern Med, 3:659-69;

3. He F.J., Nowson C.A., MacGregor G.A. (2006) Fruit and vegetable consumption and stroke: meta-analysis of cohort studies. Lancet, 367(9507):320-6;

4. Guenther P.M., Dodd K.W., Reedy J., Krebs-Smith S.M. (2006) Most Americans eat much less than recommended amounts of fruits and vegetables. J Am Diet Assoc, 106:1371-1379;

5. Krølner R., Rasmussen M., Brug J., Klepp K.I., Wind M., Due P. (2011) Determinants of fruit and vegetable consumption among children and adolescents: a review of the literature. Part II: qualitative studies. Int J Behav Nutr Phys Act, 14;8:112;

6. Te Velde S.J, Twisk J.W., Brug J. (2009) Tracking of fruit and vegetable consumption from adolescence into adulthood and its longitudinal association with overweight. Br J Nutr, 98:431-438.

7. Perk J., De Backer G., Gohlke H., Graham I., Reiner Z. et al. (2012) European Guidelines on cardiovascular disease prevention in clinical practice (version 2012). European Heart Journal, 33(13):1635-701;

8. European Heart Network (2011) Diet, Physical Activity and Cardiovascular Disease Prevention. European Heart Network, Brussels;

9. Rasmussen M., Krølner R., Klepp K.I., Lytle L., Brug J., Bere E., Due P. (2006) Determinants of fruit and vegetable consumption among children and adolescents: a review of the literature. Part I: quantitative studies. Int J Behav Nutr Phys Act, 11;3:22;

10. Holst B., Williamson G. (2008) Nutrients and phytochemicals: from bioavailability to bioefficacy beyond antioxidants. Curr Opin Biotechnol,19:73-82;

11. Williamson G., Holst B. (2008). Dietary reference intake value for dietary polyphenols: are we heading in the right direction? $\mathrm{Br} J$ Nutr, 99:S55-S58;

12. Huxley R.R., Neil H.A. (2003) The relation between dietary flavonol intake and coronary heart disease mortality: a metaanalysis of prospective cohort studies. Eur J Clin Nutr, 57(8):9048;

13. Hollman P.C.H., Geelen A., Kromhout D. (2010). Dietary flavonol intake may lower stroke risk in men and women. J Nutr 2010;140:600-604;

14. Li S-H., Liu X-X., Bai Y-Y., Wang X-J., Sun K., Chen J-Z., Hui R-T. (2010) Effect of oral isoflavone supplementation on vascular endothelial function in postmenopausal women: a meta-analysis of randomized placebo-controlled trials. Am J Clin Nutr, 91:480486; 
15. EFSA Panel on Dietetic Products, Nutrition and Allergies. (2010). Scientific opinion on the substantiation of health claims related to vitamin $C$ and the reduction of tiredness and fatigue, contribution to normal psychological functions, regeneration of the reduced form of vitamin E, contribution to normal energy yielding metabolism, maintenance of the normal function of the immune system and protection of DNA, proteins and lipids from oxidative damage pursuant to Article 13 (1) of Regulation (EC) No 1924/2006. EFSA Journal, 8(10):1815;

16. Knekt P., Ritz J., Pereira M.A., O'Reilly E.J., Augustsson K., Fraser G.E., et al. (2004) Antioxidant vitamins and coronary heart disease risk: a pooled analysis of 9 cohorts. Am J Clin Nutr, 80(6):1508-20,

17. Appel L.J., Moore T.J., Obarzanek E., Vollmer W.M., Svetkey L.P., Sacks F.M., et al. (1997) A clinical trial of the effects of dietary patterns on blood pressure. DASH Collaborative Research Group. N Engl J Med, 336:1117-24;

18. World Health Organization (1990) Diet, Nutrition and the Prevention of Chronic Diseases. WHO Technical Report, Series 797. Geneva: World Health Organization;

19. Keenan J.M., Pins J.J., Frazel C., Moran A., Turnquist L. (2002) Oat ingestion reduces systolic and diastolic blood pressure in patients with mild or borderline hypertension: a pilot trial. J Fam Prac, 51(4):369;

20. Chandalia M., Garg A., Lutjohann D., von Bergmann K., Grundy S.M., Brinkley L.J. (2000) Beneficial effects of high dietary fiber intake in patients with type 2 diabetes mellitus. N Engl J Med, 342(19):1392-8;

21. Pereira M.A., O'Reilly E., Augustsson K., Fraser G.E., Goldbourt U., Heitmann B.L., et al. (2004) Dietary fiber and risk of coronary heart disease: a pooled analysis of cohort studies. Arch Intern Med, 164(4):370-6;

22. Henderson L., Gregory J., Swan G. (2002) The National Diet \& Nutrition Survey: adults aged 19 to 64 years. Volume 1: Types and quantities of foods consumed. Office of National Statistics. London: HMSO;

23. Odegaard A.O., Koh W.P., Yuan J.M., Gross M.D., Pereira M.A. (2012) Western-style fast food intake and cardiometabolic risk in an Eastern country. Circulation, 126(2):182-8;

24. World Health Organization (2003) Diet, Nutrition and the Prevention of Chronic Diseases. Report of a Joint WHO/FAO Expert Consultation. WHO Technical Report Series No. 916. Geneva: World Health Organization;
25. Stender S., Dyerberg J., Astrup A. (2006) High Levels of Industrially Produced Trans Fat in Popular Fast Foods. New Engl J Med, 354:1650-2;

26. Darmon N., Drenowski A. (2008) Does social class predict diet quality? Am J Clin Nutr, 87(5):1107-17;

27. Marques-Vidal P., Ravasco P., Dias C.M., Camilo M.E. (2006) Trends of food intake in Portugal, 1987-1999: results from the National Health Surveys. European Journal of Clinical Nutrition, 60:1414-1422;

28. Savige G., Macfarlane A., Ball K., Worsley A., Crawford D. (2007) Snacking behaviours of adolescents and their association with skipping meals. International Journal of Behavioral Nutrition and Physical Activity, 4:36;

29. Jago R., Baranowski T., Baranowski J.C., Cullen K.W., Thompson D. (2007) Distance to food stores \& adolescent male fruit and vegetable consumption: mediation effects. International Journal of Behavioral Nutrition and Physical Activity, 4:35;

30. Snyder L.B. (2007) Health communication campaigns and their impact on behaviour. Journal of Nutritional Education Behavior, 39:32-40;

31. Robinson E., Harris E., Thomas J., Aveyard P., Higgs S. (2013) Reducing high calorie snack food in young adults: a role for social norms and health based messages. Int J Behav Nutr Phys Act, 5;10(1):73. 